\title{
基于非结构化VOSET方法的沸腾传热
}

\author{
曹志柱 ${ }^{1}$, 孙东亮 ${ }^{2 *}$, 魏进家 ${ }^{1,3}$, 宇波 ${ }^{2 *}$ \\ 1. 西安交通大学化学工程与技术学院, 西安 710049; \\ 2. 北京石油化工学院机械工程学院, 北京 102617 ; \\ 3. 西安交通大学动力工程多相流国家重点实验室, 西安 710049 \\ *联系人, E-mail: sundongliang@bipt.edu.cn; yubobox@vip.163.com
}

2019-09-27 收稿, 2019-11-25 修回, 2019-11-26 接受, 2020-03-30 网络版发表

国家自然科学基金(51636006，51776019)、北京市自然科学基金委员会-北京市教育委员会联合项目(KZ201810017023)、长城学者培养计划 (CIT\&TCD20180313)和高水平创新团队建设计划(IDHT20170507)资助

\begin{abstract}
摘要 将非结构化VOSET方法推广至求解气液界面存在相变的流动传热问题. 为准确计算界面两侧因相变导致的 能量跳跃，给出了含界面非结构网格控制单元温度的计算方法，并对非界面网格温度场采用隐式求解以提高计算 精度. 为验证所构建相变模型的正确性, 编写程序分别模拟了恒壁面过热度和恒热流密度两种边界条件下的水平 表面膜态沸腾, 计算结果与Klimenko经验关联式吻合良好. 通过圆弧表面膜态沸腾问题, 验证了本文基于带相变非 结构VOSET方法对不规则区域沸腾相变问题的适用性. 通过模拟近临界压力水的膜态沸腾问题，并与 Berenson和 Klimenko经验关联式对比, 验证了本文方法对实际沸腾问题的适用性.
\end{abstract}

关键词 相变, VOSET, 膜态沸腾, 非结构化网格

对于存在相变的流动传热问题，相界面附近速度 场、能量场不连续. 如何将相变带来的影响(相变传质 传热)反映到流场求解中, 成为沸腾相变数值模拟研究 的重点. 界面追踪方法是多相流研究的重要内容, 流体 体积法(volume of fluid, VOF) ${ }^{[1]}$ 和水平集(level set, LS $)^{[2]}$ 方法是两种典型且使用最广泛的界面追踪方法. Welch和Wilson ${ }^{[3]}$ 首先将VOF方法应用于模拟水平面的 膜态沸腾过程. 随后, Agarwal等人 ${ }^{[4]}$ 采用VOF方法成功 预测了水平膜态沸腾气泡的生长和传热特征，计算得 到的努塞尔数仅比Klimeno关联式 ${ }^{[5]}$ 低 $7.6 \%$. Yuan等 人 $^{[6]}$ 将VOF方法拓展至适体坐标，模拟了强制对流膜 态沸腾，计算得到的气液界面演化过程与实验吻合良 好. Pan等人 ${ }^{[7]}$ 基于VOF法，提出了一种可大大减少计 算时间的相变模型，模型源项与当地温度耦合显式求 解, 得到了较为准确的微通道内气泡生长运动、液膜 厚度以及壁面传热系数. LS方法已被用于求解各种沸
腾问题, Son 和Dhir ${ }^{[8]}$ 首先采用LS方法求解了膜态沸腾 问题. 随后, Dhir课题组对该方法进行了改进, 并研究 了池沸腾中单个气泡的生长和脱离过程 ${ }^{[9]}$ 、单个成核 点产生的多气泡坚直和水平方向的融合过程 ${ }^{[10,11]}$, 计 算结果均与实验相吻合. 此外, Dhir课题组 ${ }^{[12]}$ 还结合移 动网格技术, 研究了不同重力水平下过冷池沸腾中单 气泡的动力学行为和传热特性, 发现过冷度在微重力 下对气泡尺寸的影响更显著. Gibou等人 ${ }^{[13]}$ 使用虚拟流 体方法实施了相界面边界条件, 研究了二维膜态沸腾 过程, 计算结果在定性上与实验吻合. $\mathrm{Li}$ 等人 ${ }^{[14]}$ 采用耦 合相变的LS方法研究了加热面厚度对FC-72单气泡饱 和沸腾的热响应规律.

VOSET方法 ${ }^{[15]}$ 是一种复合的VOF和Level set方法, 较传统的VOF和Level set方法优势明显. VOSET方法 中, 符号距离函数采用简单的迭代几何方法计算得到, 整个计算仅需在界面附近有限的标识网格区域内进行, 
无需如传统Level set方法整场迭代求解符号距离函数 对流方程和重新初始化方程, 因此计算过程大为简化. VOSET兼顾了表面张力计算的精度和质量守恒特性, 因此有望成为研究复杂相界面演化问题(如沸腾过程) 的重要工具，先后被推广用于膜态沸腾 ${ }^{[16,17]}$ 和核态沸 腾 ${ }^{[18,19]}$ 等问题的研究. 但上述研究主要基于结构化网 格，难于求解复杂区域多相流的相变传热问题. 因此, 作者前期发展了非结构化网格VOSET ${ }^{[20 ~ 22]}$ 和适体结构 化网格VOSET ${ }^{[23]}$, 有效解决了VOSET难以应用到复杂 不规则区域气液两相流问题的不足. 本文在这些前期 工作的基础上，构建基于非结构网格的带相变VOSET 方法，进一步将非结构化VOSET方法推广至可求解气 液界面存在相变的流动传热问题. 本文的主要研究内 容如下：首先，构建基于非结构化网格VOSET的相变 模型，给出界面两侧能量跳跃温度场的计算方法; 其 次, 将相变传热传质作为源项加人到流场求解中, 编写
带相变的SIMPLE程序; 然后, 为验证所构建相变模型 的正确性，分别模拟恒壁面热流密度和恒壁温两种边 界条件下的水平表面膜态沸腾，计算结果与经验关联 式进行对比; 最后, 为验证对不规则区域问题和实际工 质沸腾过程的通用性，分别模拟圆弧表面和近临界压 力水的膜态沸腾过程.

\section{1 数值方法}

\section{1 流动控制方程}

本文中, 考虑气相为目标流体, 即相函数 $\alpha=1$ 的区 域均为气相. 无相变的不可压缩的两相流控制方程包 括体积分数方程、连续性方程、动量方程:

$$
\begin{aligned}
& \frac{\partial \alpha}{\partial t}+\boldsymbol{u} \nabla \alpha=0, \\
& \nabla \cdot \boldsymbol{u}=0,
\end{aligned}
$$

$\frac{\partial \boldsymbol{u}}{\partial \tau}+(\boldsymbol{u} \nabla) \boldsymbol{u}=\frac{1}{\rho_{\varepsilon}(\phi)}\left\{-\nabla p+\nabla \cdot \mu_{\varepsilon}(\phi)\left[\nabla \boldsymbol{u}+(\nabla \boldsymbol{u})^{\mathrm{T}}\right]+\rho_{\varepsilon}(\phi) \boldsymbol{g}+\sigma \kappa(\phi) \nabla H(\phi)\right\}$.

方程(3)最后一项为表面张力项, 其中 $\sigma$ 为表面张力 系数, $\kappa(\phi)$ 为界面曲率, $H(\phi)$ 为Heaviside函数. 对于上述 方程在非结构化网格的离散求解, 详见文献[20].

当气液界面发生相变时，界面附近存在气相和液 相的相互转化, 导致两侧的速度能量存在跳跃 ${ }^{[16 ~ 18]}$. 此 时, 相界面网格单元连续性方程应包含相变带来的体 积膨胀源项:

$\nabla \cdot \boldsymbol{u}=\dot{m}\left(\frac{1}{\rho_{\mathrm{v}}}-\frac{1}{\rho_{1}}\right)$,

其中, $\dot{m}$ 为相变带来的通过界面的质量流量, $\rho_{\mathrm{v}}$ 和 $\rho_{1}$ 分 别为气相和液相密度. 对某含相界面网格, 将液相区域 温度近似为饱和温度, 因界面 $\Gamma$ 上存在蒸发或凝结产生 的质量流量满足

$$
\int_{V} \dot{m} \mathrm{~d} V=\frac{1}{\gamma} \int_{\Gamma} \dot{q} \mathrm{~d} S=\left.\frac{1}{\gamma} \int_{\Gamma} \lambda_{\mathrm{v}} \frac{\partial T}{\partial n}\right|_{\mathrm{v}} \mathrm{d} S,
$$

其中, $\gamma$ 为汽化潜热, 单位 $\mathrm{J} / \mathrm{kg}$, 表征温度不变时, 单位质 量液相物质在汽化过程中吸收的热量.

根据质量守恒可得相应的带相变体积分数方程

$$
\frac{\partial \alpha}{\partial t}+\boldsymbol{u} \nabla \alpha=\frac{\rho_{1}}{\rho_{1}-\rho_{\mathrm{v}}} \nabla \cdot \boldsymbol{u} .
$$

将结合相变模型的两相流控制方程基于同位网格 进行离散求解, 采用有限容积方法将 $\mathrm{NS}$ 方程在任一 $N$ 边形(或 $N$ 面体)上离散, 可得动量方程离散形式:

$$
a_{P_{0}} \phi_{P_{0}}=\sum_{j=1}^{N} a_{j} \phi_{P_{j}}+b_{0},
$$

其中, 离散系数

$$
\begin{aligned}
a_{P_{0}}= & -S_{P} V_{P_{0}}+\sum_{j=1}^{N} a_{j}+\frac{\rho_{P_{0}} V_{P_{0}}}{\Delta t}, a_{j}=\frac{\mu_{\varepsilon}\left(\phi_{j}\right)}{\left|\boldsymbol{d}_{j}\right|^{2}}\left(\boldsymbol{d}_{f} \boldsymbol{A}_{j}\right)+\left[\max \left(\rho_{j} \boldsymbol{u}_{j} \boldsymbol{A}_{j}, 0\right)-\rho_{j} \boldsymbol{u}_{j} \boldsymbol{A}_{j}\right], \\
b_{0}= & \sum_{j=1}^{N} \mu_{\varepsilon}\left(\phi_{j}\right)\left[(\nabla \phi)_{j}-(\nabla \phi)_{j} \frac{\boldsymbol{d}_{j}}{\left|\boldsymbol{d}_{j}\right|} \frac{\boldsymbol{d}_{j}}{\left|\boldsymbol{d}_{j}\right|}\right] \boldsymbol{A}_{j}+\frac{\rho_{P_{0}}^{0} \phi_{P_{0}}^{0}}{\Delta t} V_{P_{0}}+S_{C} V_{P_{0}}+ \\
& \sum_{j=1}^{N} \gamma(\nabla \phi)_{j}\left[\left(\boldsymbol{r}_{j}-\boldsymbol{r}_{P_{0}}\right) \max \left(\rho_{j} \boldsymbol{u}_{j}, 0\right)+\left(\boldsymbol{r}_{j}-\boldsymbol{r}_{P_{j}}\right) \max \left(-\rho_{j} \boldsymbol{u}_{j}, 0\right)\right] \boldsymbol{A}_{j} .
\end{aligned}
$$


对流项采用延迟修正的二阶中心差分格式，扩散 项中界面梯度由相邻控制中心的物理量插值获得, 控 制中心的梯度采用最小二乘法计算，源项 $b_{0}$ 中的速度 相关项由延迟修正得到. 由于同位网格中所有待求变 量都存储在网格中心，动量方程的压力梯度项采用中 心差分时，不易检测并消除迭代求解出现的棋盘式波 形压力场. 为了保证压力和速度不失耦, 本文采用Rhie 和Chow ${ }^{[24]}$ 提出的动量插值法, 在求解过程中引人 $1-\delta$ 压差.

在结构化同位网格上将 $u$ 动量方程对控制容积 $P$ 积
分后离散得

$$
\begin{aligned}
u_{P} & =\left(\sum a_{n b} u_{n b}^{*}+b\right) /\left(a_{P} / \alpha_{u}\right)+d_{P}\left(p_{w}-p_{e}\right) \\
& =\widetilde{u}_{P}^{*}+d_{P}\left(p_{w}-p_{e}\right) .
\end{aligned}
$$

类似地, 界面 $e$ 上 $u$ 的离散方程为

$$
\begin{aligned}
u_{e} & =\left(\sum a_{n b} u_{n b}^{*}+b\right) /\left(a_{e} / \alpha_{u}\right)+d_{e}\left(p_{P}-p_{E}\right) \\
& =\widetilde{u}_{e}^{*}+d_{e}\left(p_{P}-p_{E}\right),
\end{aligned}
$$

式中, $\widetilde{u}_{e}^{*}$ 由相邻控制节点的速度 $u_{P}$ 和 $u_{E}$ 减去各自的压 力项后平均得到, 整理可得界面 $e$ 上的动量插值公式:

$$
\begin{aligned}
u_{e} & =\widetilde{u}_{e}^{*}+d_{\mathrm{e}}\left(p_{P}-p_{E}\right)=0.5\left(u_{E}-d_{E}\left(p_{e}-p_{e e}\right)+u_{P}-d_{P}\left(p_{w}-p_{e}\right)\right)+d_{e}\left(p_{P}-p_{E}\right) \\
& =0.5\left(u_{E}+u_{P}\right)+d_{e}\left(p_{P}-p_{E}\right)-0.5\left(d_{E}\left(p_{e}-p_{e e}\right)+d_{P}\left(p_{w}-p_{e}\right)\right) .
\end{aligned}
$$

当 $d_{e}$ 非常精确时, 下划线部分为 0 , 但在数值离散过 程中 $d_{e}=\left(d_{E}+d_{P}\right) / 2$, 因假定压力呈线性分布而引人误 差, 导致下划线项很难为 0 . 该项的精度直接决定了连 续性方程的收玫情况，其对体积分数和距离的准确计 算影响很大, 比如当连续性方程收玫较差时, 容易出现 本应满网格的网格被判断为含相界面网格. 因此, 在动 量插值法中，界面速度表示为相邻节点的真实速度平 均和邻点压力项时, 下划线压力项需引人松驰系数, 以 加速连续性方程的收玫. 对非结构化同位网格, 类似地, 可得到引人松驰系数后的界面流速表达式:

$$
\begin{gathered}
\boldsymbol{u}_{j}=w_{P_{0}} \boldsymbol{u}_{P_{0}}+w_{P_{j}} \boldsymbol{u}_{P_{j}}+\frac{\alpha_{\text {relax }}}{2}\left[\left(\frac{V}{a_{P_{0}}^{u}}\right)_{P_{0}}+\left(\frac{V}{a_{P_{0}}^{u}}\right)_{P_{j}}\right] \\
\left\{\frac{1}{2}\left[(\nabla p)_{P_{0}} \cdot \frac{\boldsymbol{d}_{j}}{\left|\boldsymbol{d}_{j}\right|}+(\nabla p)_{P_{j}} \cdot \frac{\boldsymbol{d}_{j}}{\left|\boldsymbol{d}_{j}\right|}\right]-\frac{p_{P_{j}}-p_{P_{0}}}{\left|\boldsymbol{d}_{j}\right|}\right\} \frac{\boldsymbol{A}_{j}}{\left|\boldsymbol{A}_{j}\right|} .
\end{gathered}
$$

\section{2 温度场求解}

针对膜态沸腾问题，将温度场求解分为 3 种情况： (1) 对于液相区域, 温度近似为饱和温度; (2) 对于纯气 相区域, 采用单相温度控制方程(式(13))求解, 其离散详 见文献[24]; (3) 含相界面的网格中心点温度采用插值 方法求解:

$\frac{\partial\left(\rho c_{p} T\right)}{\partial t}+\nabla \cdot\left(\rho c_{p} \boldsymbol{u} T\right)=\nabla \cdot(\lambda \nabla T)$.

如图1所示, 对第3种网格内含相变界面情况, 需根 据体积分数大小分两种情况确定该控制中心点温度. 当 $\alpha<0.5$ 时，
$T_{i}=T_{\text {sat }}$

当 $\alpha \geq 0.5$ 时,

$\frac{\partial T}{\partial n} \approx \frac{T_{i}-T_{\mathrm{sat}}}{D}=-\left(T_{x} n_{x}+T_{y} n_{y}\right)$.

因此,

$T_{i} \approx T_{\mathrm{sat}}-D\left(T_{x} n_{x}+T_{y} n_{y}\right)$.

其中, $T_{x}$ 和 $T_{y}$ 为界面上的温度梯度分量, $n_{x}$ 和 $n_{y}$ 为单位 界面法向向量在 $x$ 和 $y$ 方向的分量, $D$ 为界面网格中心到 相界面的最短距离. 在传统VOF中, 该向量一般采用体 积分数梯度计算, 由于体积分数函数是不连续函数, 因

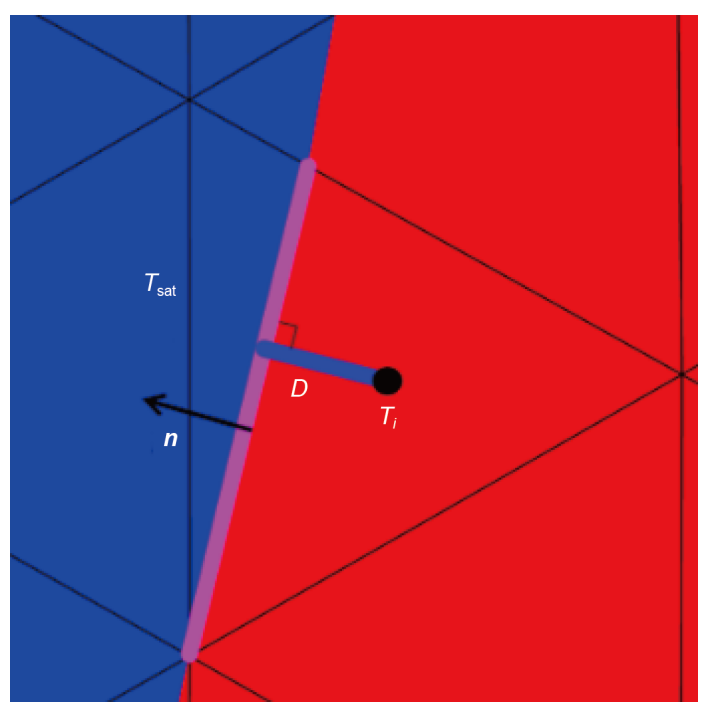

图 1 (网络版彩色)含相界面网格单元中心点的温度计算

Figure 1 (Color online) Temperature calculation on central points of interfacial grid cells 
此所得到的法向向量精度较低. 在本文采用的VOSET 方法中, 该向量采用连续的符号距离函数计算, 故可得 到较准确的法向向量:

$\boldsymbol{n}=\nabla \phi /|\nabla \phi|$.

\section{3 界面温度梯度求解}

非结构化网格温度梯度的求解精度，特别是含界 面单元梯度的精度，对温度场及相变量准确计算影响 较大. 本文求解界面温度梯度的步骤如下:

(1) 对任意含界面非结构三角形网格, 采用VOSET 方法重构界面 ${ }^{[20]}$, 获得界面与控制单元边界的交点 $(\mathrm{E}$ 和 $F$ 点)坐标.

（2）已知界面线段中点 $\mathrm{M}$ 点坐标 $\left(x_{\mathrm{m}}, y_{\mathrm{m}}\right)$, 沿界面法 向朝目标流体区域方向 $l$ 距离上确定点S. S点坐标 $\left(x_{\mathrm{s}}\right.$, $y_{\mathrm{s}}$ ) 为

$x_{s}=-\ln n_{x}+x_{m}$,
$y_{s}=-\ln n_{y}+y_{m}$.

(3) 采用插值法计算 $S$ 点温度. 先确定该点所在单 元编号, 然后计算该单元各顶点温度, 最后通过插值法 得到 $\mathrm{S}$ 点温度 $T_{\mathrm{s}}$.

(4) 计算界面温度梯度:

$\frac{\partial T}{\partial n} \approx \frac{T_{\mathrm{s}}-T_{\mathrm{sat}}}{l}$.

值得注意的是，为简便上面只给出了一阶离散逼 近算法. 构建二阶格式时，步骤类似，只需在界面法向 目标流体区域方向 $2 l$ 距离上增加一个辅助点.

\section{2 带相变VOSET方法验证与结果分析}

理论研究 ${ }^{[5,25]}$ 认为, 在水平板膜态沸腾过程中, 气 液界面处于波动状态，存在Taylor不稳定现象. 在这种 不稳定性的作用下，气膜波峰处的蒸汽会周期性地与 气膜脱离并进入液体中, 相应的Taylor不稳定波长 $\lambda_{0}$ 为

$\lambda_{0}=2 \pi \sqrt{\frac{3 \sigma}{\left(\rho_{1}-\rho_{\mathrm{v}}\right) g}}$.

引人空间平均 $\overline{N u}$ 和时空平均 $\overline{N u}$ :

$\overline{N u}=\frac{2}{\lambda_{0}} \int_{0}^{\lambda 0^{\prime 2}} N u \mathrm{~d} x$,

$\overline{N u}=\frac{2}{t_{p} \lambda_{0}} \int_{0}^{t_{p}} \int_{0}^{\lambda_{0} / 2} N u \mathrm{~d} x \mathrm{~d} t$,

式中, $N u$ 表示某时刻加热面附近的当地努塞尔数:
$N u=\left.\frac{\lambda^{\prime}}{\left(T_{\mathrm{wall}}-T_{\mathrm{sat}}\right)} \frac{\partial T}{\partial y}\right|_{y=0}$,

式中, $\lambda^{\prime}$ 为特征尺度, $\lambda^{\prime}=\sqrt{\frac{\sigma}{\left(\rho_{1}-\rho_{\mathrm{v}}\right) g}}$.

为了验证所构建相变模型的正确性，分别对恒壁 面无量纲热流密度 $\left(\chi_{\mathrm{w}}=20.0\right.$, 算例1)的水平板膜态沸 腾问题和恒壁面过热度(过热度 $5 \mathrm{~K}$, 算例2)的水平板膜 态沸腾问题进行模拟，将计算结果与经验关联式对比. 同时，为了验证本文基于非结构VOSET相变模型对不 规则区域问题的适用性，算例3中沸腾加热面为圆形 面. 算例 4 为近临界压力下水的膜态沸腾算例，用于说 明本文数值方法对实际沸腾问题的通用性.

\section{1 恒壁面热流密度水平板膜态沸腾}

在该算例中，相变产生的蒸汽通过气带与气膜连 接, 气膜产生的蒸汽不断进人使气泡不断长大. 根据对 称性, 横向取 0.5 倍波长, 纵向取 1.5 倍波长, 即计算区域 为 $\left[0 \sim 0.5 \lambda_{0}, 0 \sim 1.5 \lambda_{0}\right]$. 上边界为开口边界, 左右边界采用 对称性边界条件, 底部为无滑移固体壁面, 如图2所示. 横向取 100 网格, 纵向取 300 网格, 计算网格为 67512 个. 计算时间为 $0.48 \mathrm{~s}$, 采用库朗数 $C F L=0.05$ 控制时间步长, 最大时间步长不超过 $10^{-4} \mathrm{~s}$. 物性参数见表 1 .

初始气液界面满足如下关系式:

$y=\left(24.0-3.8 \cos \left(\frac{2 \pi x}{\lambda_{0}}\right)\right) l_{0}$.

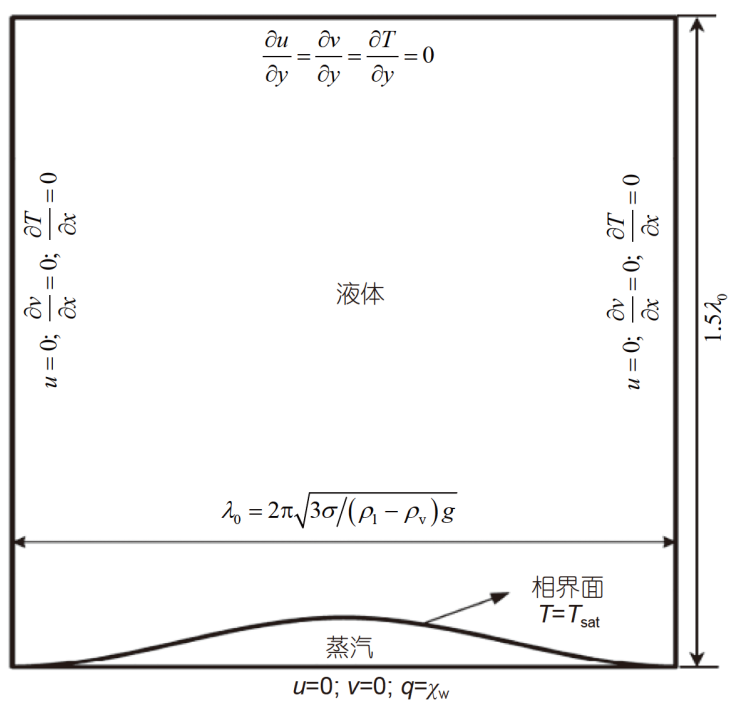

图 2 恒壁面热流密度膜态沸腾的计算区域和边界条件

Figure 2 The computational domain and boundary conditions in the constant heat flux film boiling case 
表 1 恒热流密度下水平板膜态沸腾的流体物性参数

Table 1 The parameters in the constant heat flux film boiling on the horizontal plate

\begin{tabular}{ccccccc}
\hline & 密度 $\left(\mathrm{kg} / \mathrm{m}^{3}\right)$ & 黏度 $(\mathrm{Pa} \mathrm{s})$ & 导热系数 $(\mathrm{W} /(\mathrm{m} \mathrm{K}))$ & 比热容 $(\mathrm{J} /(\mathrm{kg} \mathrm{K}))$ & 汽化潜热 $(\mathrm{J} / \mathrm{kg})$ & 表面张力系数 $(\mathrm{N} / \mathrm{m})$ \\
\hline 气体 & 103.6 & 0.03 & 1.03 & 60.1 & 716.1 & \\
液体 & 541.1 & 0.1 & 3.51 & 53.0 & & 1.2 \\
\hline
\end{tabular}

取无量纲热流密度 $\chi_{\mathrm{w}}=20.0$ (等价于 $\left.q_{\mathrm{w}}=12.0 \mathrm{~W} / \mathrm{cm}^{2}\right)$. 液相始终保持饱和状态, 初始时刻整个计算区域为饱 和温度 $T_{0}=29.91{ }^{\circ} \mathrm{C}$. 图3给出了恒壁面热流密度下两相 流体在不同时刻的温度分布及相界面位置，可以看到， 在相变的作用下初始气膜不断增厚, 逐渐从中部凸出, 界面形状受流场影响发生形变, 最后长大呈蘑菇状, 与
文献[16]基于结构化VOSET的模拟结果吻合良好. 图4 给出了 $t=0.41 \mathrm{~s}$ 时非结构VOSET重构的沸腾相界面, 界 面光顺性较好, 验证了带相变VOSET的性能. 图5对比 了空间平均 $\mathrm{Nu}$ 随时间的变化曲线, Klimenko关联式得 到的时空平均 $\overline{\mathrm{Nu}}$ 为 0.275 , 本文数值模拟得到的时空平 均 $\overline{\mathrm{Nu}}$ 为 0.292 , 与经验关联式偏差仅为 $6.18 \%$, 再次验证 (a)

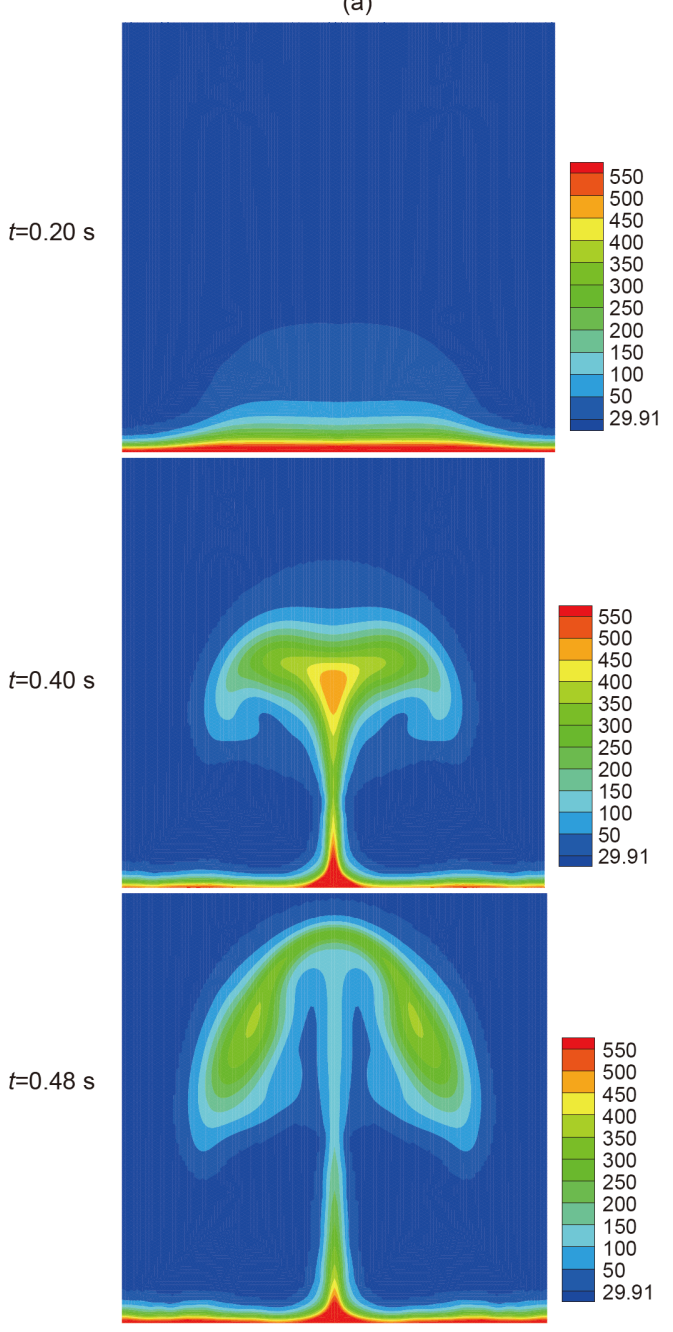

(b)
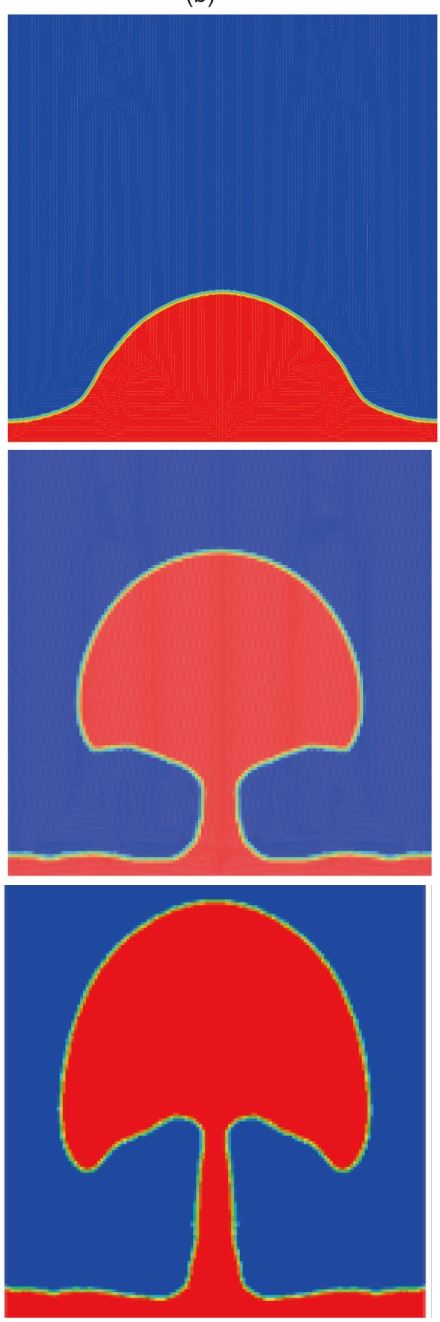

图 3 (网络版彩色)不同时刻下恒壁面热流密度膜态沸腾计算结果. (a) 温度场云图; (b) 流体体积函数云图

Figure 3 (Color online) The simulation results in the constant heat flux film boiling at different time. (a) Temperature contours; (b) volume fraction contours 


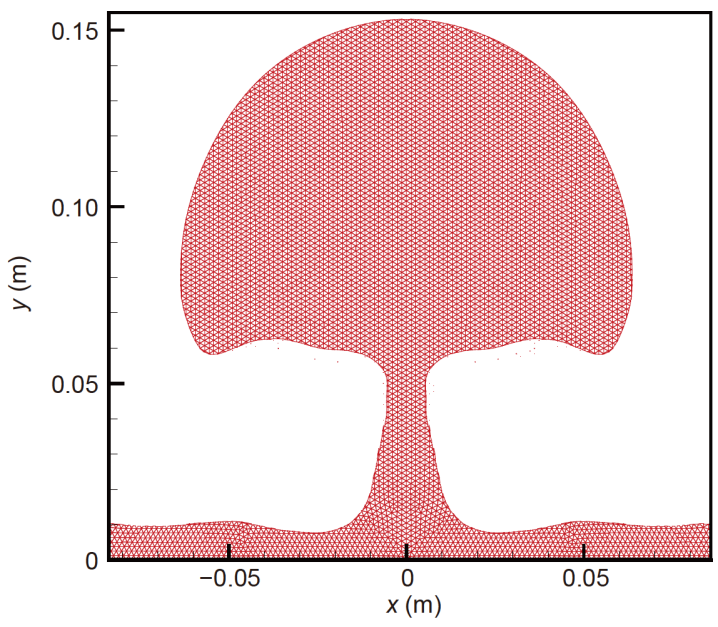

图 4 (网络版彩色) $t=0.41 \mathrm{~s}$ 时重构的恒壁面热流密度膜态沸腾界面 Figure 4 (Color online) The reconstructed interface in the constant heat flux film boiling at $t=0.41 \mathrm{~s}$

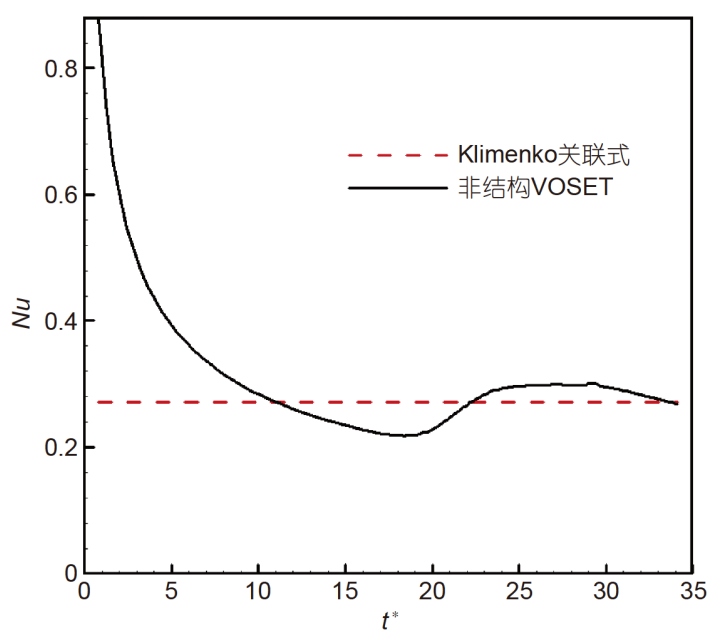

图 5 (网络版彩色)恒壁面热流密度膜态沸腾空间平均努赛尔数随 时间的变化曲线

Figure 5 (Color online) The curve of space averaged Nusselt number with time in the constant heat flux film boiling

了本文数值方法的准确性.

\section{2 恒壁面过热度水平板膜态沸腾}

根据对称性，横向取半个表波长，计算区域为 $\left[0 \sim 0.5 \lambda_{0}, 0 \sim \lambda_{0}\right]$, 流体的物性参数见表 2 . 本算例中边界 条件和算例1相同, 初始气液界面满足如下关系式:

$y=\frac{\lambda_{0}}{128}\left(4.0+\cos \left(\frac{2 \pi x}{\lambda_{0}}\right)\right)$

初始气膜温度沿纵向线性分布. 计算区域在顶部 水平方向布置 100 个网格, 左右侧壁 160 个网格, 考虑到 底部为气膜区, 传热传质现象相对剧烈, 在底部加密取 320 个网格, 共 81418 个网格. 采用库朗数 $C F L=0.05$ 控 制时间步长, 最大时间步长不超过 $10^{-4} \mathrm{~s}$.

图6给出了 $5 \mathrm{~K}$ 恒壁面过热度下两相流体在不同时 刻的温度分布及相界面位置，计算结果验证了本文基 于非结构VOSET相变模型能成功模拟水平壁面膜态沸 腾气泡的产生及逃逸脱离过程.

目前，水平板膜态沸腾气液相变的传热传质规律 一般通过相关传热关联式来定量描述，其中Klimenko 关联式 ${ }^{[5]}$ 因同时适用于层流和湍流，预测精度与实验 误差为 $\pm 25 \%$, 而得到较为广泛应用. 图7给出了非结构 VOSET和Klimenko关联式计算得到的空间平均 $\overline{N u}$ 随 时间的变化曲线. Klimenko关联式得到的时空平均 $\overline{\overline{N u}}$ 为 4.107 , 本文数值模拟总时间为 $1.4 \mathrm{~s}$, 得到的时空平 均 $\overline{\mathrm{Nu}}$ 为 3.350 , 比Klimenko关联式预测的结果偏小, 偏 差为 $18.4 \%$. 这可能是因为本文数值模拟的初始速度设 定为 0 , 减弱了沸腾前期的自然对流效果，使与纵向温 度梯度成正比的壁面附近 $N u$ 偏低. 值得指出的是, 初场 的影响会随着计算时间的增长而逐渐降低，此时模拟 得到的 $N u$ 更接近关联式. 考虑到Klimenko关联式自身 存在一定误差, 本文的模拟结果整体较合理.

\section{3 恒壁面过热度圆弧表面膜态沸腾}

为了验证本文构建的带相变非结构VOSET方法对 不规则区域内沸腾问题的适用性，采用该方法计算圆 弧表面膜态沸腾问题. 算例中采用与水平板沸腾相同 的两相流体物性参数(表2)和过热度 (5 K). 取特征尺 度 $\lambda^{\prime}$ 为圆弧直径 $D=0.00714 \mathrm{~m}$, 矩形区域大小为

表 2 恒过热度下水平板膜态沸腾的流体物性参数

Table 2 The fluid physical parameters in the constant wall temperature film boiling on the horizontal plate

\begin{tabular}{ccccccc}
\hline & 密度 $\left(\mathrm{kg} / \mathrm{m}^{3}\right)$ & 黏度 $(\mathrm{Pa} \mathrm{s})$ & 导热系数 $(\mathrm{W} /(\mathrm{m} \mathrm{K}))$ & 比热容 $(\mathrm{J} /(\mathrm{kg} \mathrm{K}))$ & 汽化潜热 $(\mathrm{J} / \mathrm{kg})$ & 表面张力系数 $(\mathrm{N} / \mathrm{m})$ \\
\hline 气体 & 5 & 0.005 & 1 & 200 & & \\
液体 & 200 & 0.1 & 40 & 400 & 100000 & 0.1 \\
\hline
\end{tabular}


(a)

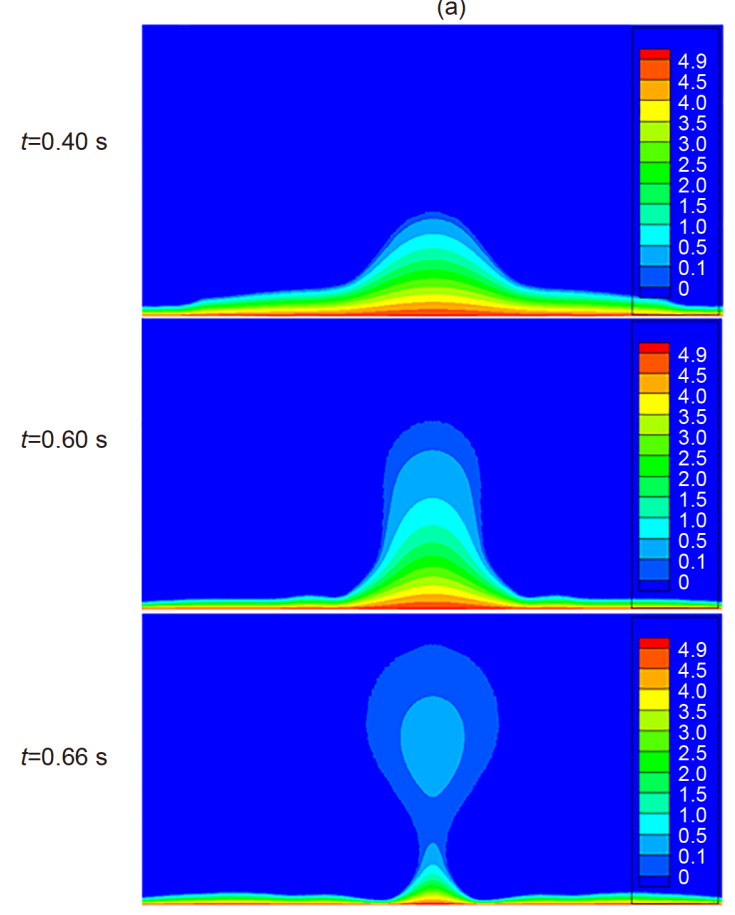

(b)
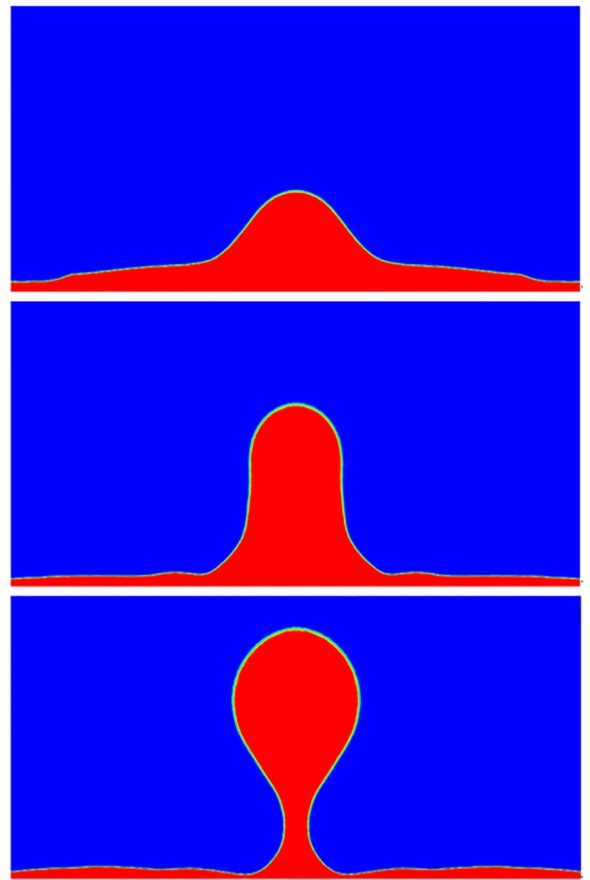

图 6 (网络版彩色)不同时刻下恒壁面过热度膜态沸腾的过热度分布及流体体积函数分布. (a) 过热度云图; (b) 流体体积函数云图 Figure 6 (Color online) The superheat distribution and volume fraction in the constant wall temperature film boiling at different times. (a) Superheat contours; (b) volume fraction contours

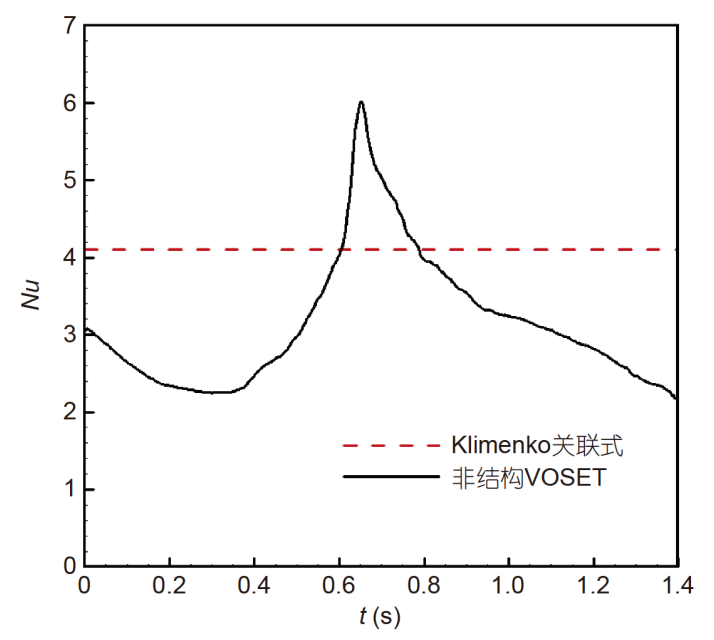

图 7 (网络版彩色)恒壁面过热度膜态沸腾空间平均努赛尔数随时 间的变化曲线

Figure 7 (Color online) The curve of space averaged Nusselt number with time in the constant wall temperature film boiling

$7 D \times 15 D$. 根据对称性, 横向计算区域减半, 计算区域取 $3.5 D \times 15 D$, 圆弧中心放置在 $(3.5 D, 3.5 D)$. 初始时刻, 厚 度为 $0.1 D$ 的气膜附着在圆弧表面, 上部为开口边界, 左 侧非圆弧为对称边界, 其他边界为滑移边界. 网格在圆

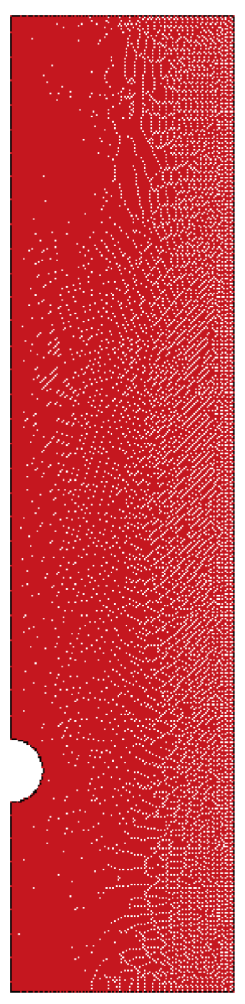

图 8 (网络版彩色)计算区域及非结构化网格

Figure 8 (Color online) Computational domain and unstructured grids 
弧及对称轴附近局部加密, 经过网格无关性计算, 计算 网格数 41750 , 如图8所示.

由于相变作用，气膜在过热的圆弧表面不断变厚， 在流场作用下逐渐在圆弧上方聚集，随后发生变形拉 伸. 图9给出了 $2.0 \mathrm{~s}$ 时带相变非结构VOSET重构的圆弧 表面沸腾气泡体积分数云图. 可以看出, 非结构VOSET 重构的相界面较为光滑, 靠近圆弧和对称轴附近由于 网格加密相界面分辨率更高, 界面更锐利. 本文结果与 文献[26]结果较为一致, 验证了带相变非结构VOSET 对不规则区域沸腾问题的通用性.

\section{4 近临界压力水在过热度为10 K时的膜态沸腾}

本算例采用开发的数值程序模拟近临界状态时水 的膜态沸腾过程. 表3给出了近临界压力时水的两相物 性参数, 计算区域为 $\left[0 \sim 0.5 \lambda_{0}, 0 \sim \lambda_{0}\right]$, 计算网格 80000 , 壁 面保持恒过热度 $10 \mathrm{~K}$. 图 10 给出了在 $t=0.40 \mathrm{~s}$ 时计算得 到的过热度分布及流体体积函数分布, 本文非结构 VOSET模拟结果和文献[16]结构化VOSET结果吻合良好.

图11给出了非结构VOSET计算出的空间平均 $N u$ 随时间的变化曲线. 由Berenson关联式 ${ }^{[25]}$ 和Klimenko

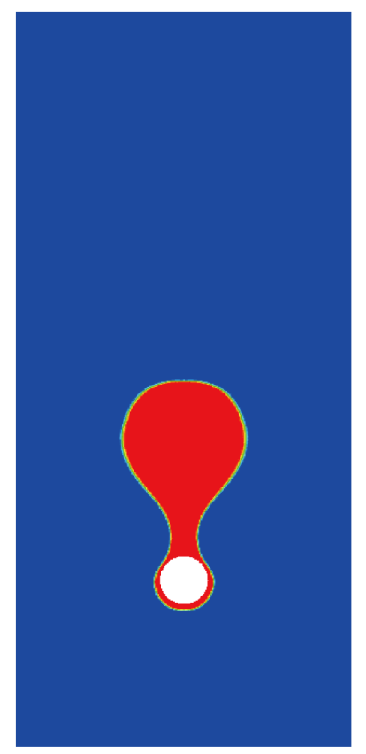

图 9 (网络版彩色) $t=2.0 \mathrm{~s}$ 时圆弧表面沸腾流体体积函数云图

Figure 9 (Color online) The computed volume fraction contours at $t=2.0 \mathrm{~s}$ during film boiling on circular surface

关联式得到的时空平均 $\overline{N u}$ 分别为 4.29 和 4.20 , 数值模拟 所得的时空平均 $\overline{N u}$ 为 4.56 , 模拟结果与经验关联式偏

表 3 近临界压力水膜态沸腾的流体物性参数

Table 3 The parameters in the film boiling of water at near critical pressure

\begin{tabular}{rcccccc}
\hline & 密度 $\left(\mathrm{kg} / \mathrm{m}^{3}\right)$ & 黏度 $(\mathrm{Pa} \mathrm{s})$ & 导热系数 $(\mathrm{W} /(\mathrm{m} \mathrm{K}))$ & 比热容 $(\mathrm{J} /(\mathrm{kg} \mathrm{K}))$ & 汽化潜热 $(\mathrm{J} / \mathrm{kg})$ & 表面张力系数 $(\mathrm{N} / \mathrm{m})$ \\
\hline 气体 & 242.7 & $3.24 \times 10^{-5}$ & 0.538 & $3.52 \times 10^{5}$ & & \\
液体 & 402.4 & $4.67 \times 10^{-5}$ & 0.545 & $2.18 \times 10^{5}$ & $2.764 \times 10^{5}$ & 0.00007 \\
\hline
\end{tabular}
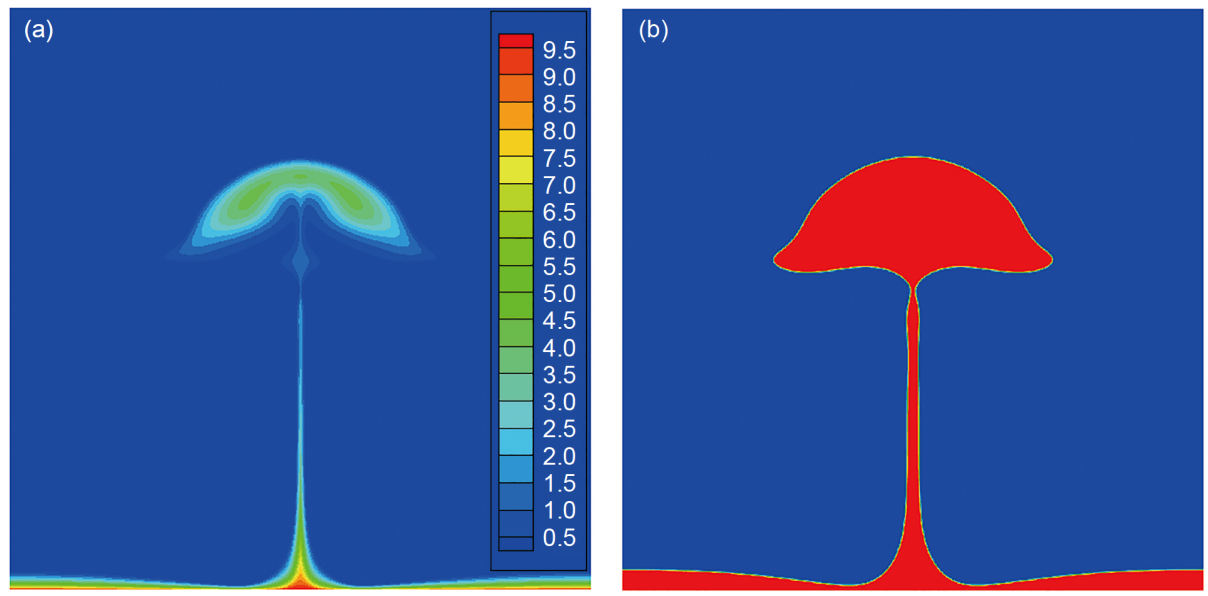

图 10 (网络版彩色) $t=0.40 \mathrm{~s}$ 时近临界压力水膜态沸腾的过热度分布及流体体积函数分布. (a) 过热度云图; (b) 流体体积函数云图

Figure 10 (Color online) The superheat distribution and volume fraction in the film boiling of water at near critical pressure at $t=0.40 \mathrm{~s}$. (a) Superheat contours; (b) volume fraction contours 
差分别为 $6.29 \%$ 和 $8.57 \%$, 验证了非结构VOSET研究实 际工质膜态沸腾问题的精确性.

\section{3 结论}

面向气液两相流动换热问题，构建了带相变非结 构VOSET方法，并通过经典算例验证了该方法的精确 性和适用性, 具体结论如下:

(1) 在非结构VOSET方法中, 一方面基于符号距离 函数获得界面法线向量, 利用插值方法, 准确计算得出 含界面非结构化网格中心点温度和界面两侧的能量跳 跃; 另一方面通过隐式求解来提高非界面网格温度场 计算的精度性.

(2) 在水平板和圆弧表面膜态沸腾两个算例中, 通 过与Klimenko经验关联式和文献结果对比分析研究, 验证了求解规正和不规则区域沸腾相变问题时，非结 构VOSET方法的精确性和适用性.

（3）在近临界压力水膜态沸腾算例中，非结构VOSET方法的计算结果与Berenson关联式和Klimenko关 联式的偏差分别仅为 $6.29 \%$ 和 $8.57 \%$ ，验证了本方法对 实际沸腾问题的适用性.

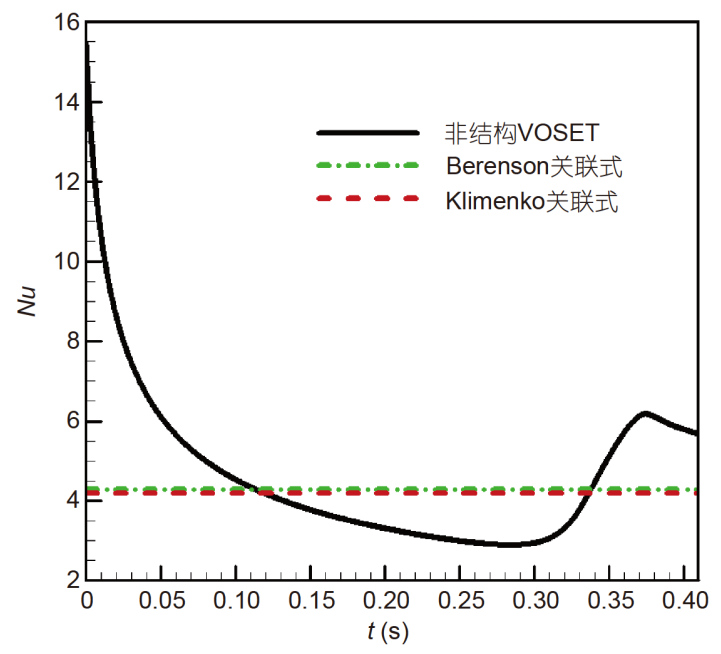

图 11 (网络版彩色)近临界压力水膜态沸腾空间平均努赛尔数随时 间的变化曲线

Figure 11 (Color online) The curve of space averaged Nusselt number with time in the film boiling of water at near critical pressure

所提出的带相变非结构VOSET方法通用性较强, 易于实现向三维问题的扩展，相应的研究成果将进一 步促进VOSET方法的推广应用.

\section{参考文献}

1 Hirt C W, Nichols B D. Volume of fluid (VOF) method for the dynamics of free boundaries. J Comput Phys, 1981, 39: 201-225

2 Osher S, Fedkiw R P. Level set methods: An overview and some recent results. J Comput Phys, 2001, 169: 463-502

3 Welch S W J, Wilson J. A volume of fluid based method for fluid flows with phase change. J Comput Phys, 2000, 160: 662-682

4 Agarwal D K, Welch S W J, Biswas G, et al. Planar simulation of bubble growth in film boiling in near-critical water using a variant of the VOF method. J Heat Transf-Trans ASME, 2004, 126: 329-338

5 Klimenko V V. Film boiling on a horizontal plate-New correlation. Int J Heat Mass Transf, 1981, 24: 69-79

6 Yuan M H, Yang Y H, Li T S, et al. Numerical simulation of film boiling on a sphere with a volume of fluid interface tracking method. Int J Heat Mass Transf, 2008, 51: 1646-1657

7 Pan Z, Weibel J A, Garimella S V. A saturated-interface-volume phase change model for simulating flow boiling. Int J Heat Mass Transf, 2016, 93: $945-956$

8 Son G, Dhir V K. Numerical simulation of film boiling near critical pressures with a level set method. J Heat Transf-Trans ASME, 1998, 120: 183192

9 Son G, Dhir V K, Ramanujapu N. Dynamics and heat transfer associated with a single bubble during nucleate boiling on a horizontal surface. J Heat Transf-Trans ASME, 1999, 121: 623-631

10 Son G, Ramanujapu N, Dhir V K. Numerical simulation of bubble merger process on a single nucleation site during pool nucleate boiling. J Heat Transf-Trans ASME, 2002, 124: 51-62

11 Mukherjee A, Dhir V K. Study of lateral merger of vapor bubbles during nucleate pool boiling. J Heat Transf-Trans ASME, 2004, 126: 1023-1039

$12 \mathrm{Wu}$ J, Dhir V. Numerical simulations of the dynamics and heat transfer associated with a single bubble in subcooled pool boiling. J Heat TransfTrans ASME, 2010, 132: 1-15

13 Gibou F, Chen L, Nguyen D, et al. A level set based sharp interface method for the multiphase incompressible Navier-Stokes equations with phase change. J Comput Phys, 2007, 222: 536-555

$14 \mathrm{Li} \mathrm{Z} \mathrm{D,} \mathrm{Zhang} \mathrm{L,} \mathrm{Zhao} \mathrm{J} \mathrm{F,} \mathrm{et} \mathrm{al.} \mathrm{Numerical} \mathrm{simulation} \mathrm{of} \mathrm{bubble} \mathrm{dynamics} \mathrm{and} \mathrm{heat} \mathrm{transfer} \mathrm{with} \mathrm{transient} \mathrm{thermal} \mathrm{response} \mathrm{of} \mathrm{solid} \mathrm{wall} \mathrm{during}$ pool boiling of FC-72. Int J Heat Mass Transf, 2015, 84: 409-418

15 Sun D L, Tao W Q. A coupled volume-of-fluid and level set (VOSET) method for computing incompressible two-phase flows. Int J Heat Mass 
Transf, 2010, 53: 645-655

16 Guo D Z. Research of two dimensional horizontal film boiling based on VOSET method (in Chinese). Doctor Dissertation. Xi'an: Xi'an Jiaotong University, 2010 [郭冬之. 基于VOSET方法的二维水平膜态沸腾研究. 博士学位论文. 西安: 西安交通大学, 2010]

17 Guo D Z, Sun D L, Li Z Y, et al. Phase change heat transfer simulation for boiling bubbles arising from a vapor film by the VOSET method. Numer Heat Transf Part A-Appl, 2011, 59: 857-881

18 Ling K, Tao W Q. Numerical simulation on film boiling in different flow pattern by VOSET (in Chinese). J Eng Thermophys, 2014, 35: 2240-2243 [凌空, 陶文铨. VOSET方法计算膜态沸腾的不同流态. 工程热物理学报, 2014, 35: 2240-2243]

19 Cao Z, Zhou J, Wei J, et al. Experimental and numerical study on bubble dynamics and heat transfer during nucleate boiling of FC-72. Int J Heat Mass Transf, 2019, 139: 822-831

20 Cao Z, Sun D, Yu B, et al. A coupled volume-of-fluid and level set (VOSET) method based on remapping algorithm for unstructured triangular grids. Int J Heat Mass Transf, 2017, 111: 232-245

21 Cao Z, Sun D, Wei J, et al. A coupled volume-of-fluid and level set method based on multi-dimensional advection for unstructured triangular meshes. Chem Eng Sci, 2018, 176: 560-579

22 Cao Z, Sun D, Yu B, et al. A coupled volume of fluid and level set method based on analytic PLIC for unstructured quadrilateral grids. Numer Heat Transf Part B-Fundamentals, 2018, 73: 189-205

23 Cao Z, Sun D, Wei J, et al. A coupled volume-of-fluid and level set method based on general curvilinear grids with accurate surface tension calculation. J Comput Phys, 2019, 396: 799-818

24 Rhie C M, Chow W L. Numerical study of the turbulent flow past an airfoil with trailing edge separation. AIAA J, 1983, 21: 1525-1532

25 Berenson P J. Film-boiling heat transfer from a horizontal surface. J Heat Transf-Trans ASME, 1961, 83: 351-356

26 Tsui Y Y, Lin S W, Lai Y N, et al. Phase change calculations for film boiling flows. Int J Heat Mass Transf, 2014, 70: 745-757 


\title{
Boiling heat transfer by using the VOSET method based on unstructured grids
}

\author{
Zhizhu Cao ${ }^{1}$, Dongliang Sun ${ }^{2 *}$, Jinjia $\mathrm{Wei}^{1,3} \&$ Bo $\mathrm{Yu}^{2 *}$ \\ ${ }^{1}$ School of Chemical Engineering and Technology, Xi'an Jiaotong University, Xi'an 710049, China; \\ ${ }^{2}$ School of Mechanical Engineering, Beijing Institute of Petrochemical Technology, Beijing 102617, China; \\ ${ }^{3}$ State Key Laboratory of Multiphase Flow in Power Engineering, Xi'an Jiaotong University, Xi'an 710049, China \\ * Corresponding authors, E-mail: sundongliang@bipt.edu.cn; yubobox@vip.163.com
}

It is well known that the fluid mass is not conserved by the level set methods while the accuracy of volume-of-fluid (VOF) methods is highly dependent on the calculation of interface normal and curvature from volume fractions. Advanced interfacial tracking methods appear by combining the two techniques to compensate each other. The coupled VOF and level set method named VOSET is one of such methods. This paper presents the extension work to include heat and mass transfer due to phase change for the VOSET method on an unstructured triangular grid. In this method, the liquid/gas interface is tracked by the VOSET method, which combines the advantages of both VOF and level set methods. The proposed method can not only preserve mass conservation but also facilitate the interface normal and curvature calculation with a high accuracy. The interfacial tracking methods are integrated to Navier-Stokes solvers accordingly. A critical issue for the mass transfer across the boiling interface is the treatment of energy jump. We propose a numerical algorithm to model energy jump based on VOSET for unstructured grids. The heat flux on each side of the interface within an interface cell needs to be computed separately. The interface is tackled as an internal boundary for temperature field. For cells with a pure phase, unlike previous studies, we solve the energy equation in an implicit way. For cells with a liquid/gas phase interface, an interpolation algorithm is developed to calculate the temperature. To validate the present numerical method, four classical boiling tests are implemented. To be specific, the first case is the constant heat flux film boiling on the horizontal plate. In this case, dimensionless wall heat flux 20.0 is set up for the bottom solid wall. The top boundary is open and the fluid is allowed to exit, no slip boundary is set to the bottom, periodic condition is set to the left boundary and symmetrical condition is imposed on the right boundary to save computational cost. The comparison of the Nusselt number with the analytical Klimenko correlation indicates that the difference between them is only $6.18 \%$. The second case is the constant wall temperature film boiling on the horizontal plate. In this case, the boundary conditions are the same with the first case except for the bottom boundary, where the wall temperature keeps at $5 \mathrm{~K}$. The computed space and time averaged Nusselt number agrees well with Klimenko correlation. Moreover, the results match well with those reported by Guo et al. qualitatively. The third case is the film boiling process on a circular surface, which is designed and simulated to verify the robustness of the present method dealing with boiling in complex domain. The numerical results demonstrate that the proposed numerical method can calculate the two phase boiling flow in irregular regions accurately. Finally, the research of film boiling of water at near-critical pressure is conducted. In this case, the wall superheat is set to be $10 \mathrm{~K}$. The numerical results are consistent with those obtained by other methods in literatures, indicating the flexibility of the present numerical method to deal with real boiling problems.

phase change, VOSET, film boiling, unstructured grids

doi: 10.1360/TB-2019-0573 